"This is an Accepted Manuscript of an article published by Taylor \& Francis in British Journal of Religious Education 2018,40(3), 337-347, available online: http://www.tandfonline.com/ 10.1080/01416200.2017.1352487.”

This document has been downloaded from TamPub.uta.fi The Institutional Repository of University of Tampere

\title{
A Comparative Study of how Social Cohesion is taught in Islamic Religious Education in
}

\section{Finland and Ireland}

Inkeri Rissanen \& Youcef Sai

\section{Abstract}

Based on classroom observations and semi-structured interviews with teachers, parents and students, this comparative study looks at how social cohesion is promoted in Islamic Religious Education [IRE] lessons in Muslim schools in Ireland and non-faith schools in Finland. The study analyses teaching in the following areas: intra-religious cohesion; interreligious cohesion and commitment to society. The findings reveal that despite differences in the governance of IRE as a subject taught in both types of schools, the IRE classroom emerges as a space whereby teachers use power as agents for internal governance of religion. The authors conclude with some implications and offer some considerations for future research and practice.

Key words: Islamic Religious Education, Social Cohesion, Finland, Ireland

\section{Introduction-Islamic Religious Education in Europe}

During the past decade, religious education has increasingly become a topic of political interest and an important arena of multicultural education, which is expected to answer the needs of an increasingly diverse European society (Revell 2012, 26-29). The role of religious education in public discourse and the recognition of its potential to contribute to both dialogue and the resolving of conflicts have stimulated academic research. Recommendations for religious education at new European-level, such as the Council of Europe publication 'Signposts' is one notable contribution (Jackson 2014). In this publication, religious education is presented in the broad context of intercultural education. While it is acknowledged that there can be no common "European solution" that would fit for the different European countries, the similarity of challenges in these contexts has given reasons for emphasising religious education primarily as a means to promote social cohesion. European countries are encouraged to develop approaches to religious education that promote understanding of religions through developing competences and dialogue, and cultivate appropriate attitudes and values such as tolerance and civic-mindedness (Jackson 2014 33).

Although not explicitly stated it appears that the increased presence of Muslim populations in European societies correlates strongly with the sudden political interest in religious education and its potential in promoting social cohesion and democratic citizenship. Currently, minority rights in Europe are exceedingly tied to demands of loyalty to the nation states and their core values, and many European nations endeavour to regulate the values of their citizens through, for example, their respective educational systems (Himanen 2012). Koenig (2007) states that 'Muslim Europeans are seen less as participants in the construction of a new, transnational collective identity but more as a 
policy problem to be "managed"'(p.927). European governments' policies increasingly include active management of religious minorities, and religious education has become a site of governance of religion (Sakaranaho, forthcoming). In the UK, for example, pressure has been put on the government to regulate madrasahs amidst suspicions of physical abuse of children, indoctrination and the promotion of extremism (Wintour 2014). In 2005, the Chief Inspector of Schools for England, David Bell, expressed concern that Muslim schools were "undermining the coherence of British society" by not adequately preparing their pupils to accept or at least understand its values (Lightfoot 2005). In the aftermath of the London bombings in 2005, this issue took on greater importance and resulted in the launch of special programs for the development of citizenship education within several Muslim faith schools (Mandaville 2007). Islamic religious education, in general, has invoked suspicions and public debates in several European countries, but studies conducted in Sweden (Berglund 2010) and Germany (Heimbrock 2007) observed that teachers of Islamic religious education supported the students' willingness to embrace the values and norms of liberal democracies.

A common trend towards integrating Islam into European educational systems is evident, but there is no uniform trend in its structure and approach. The ways in which education for Muslims is organised depend on many local factors related to the place of religion in the society, the nature of the educational system and the general approach to religious education (see Aslan 2009). Approximately half of all European countries have given some effort to include Islam in some form or another, as a subject in the curriculum or as extra-curricular subject, in public school instruction (Maréchal 2002). When IRE is implemented, it is often understood as a form of diversity management and as a way of coping with problems related to the integration of migrant Muslims (Veinguer, Dietz, Jozsa \& Knauth 2009).

Public schools, where the majority of European Muslims are educated, are often posited as the best way to integration. The fact that some Muslims want their own education invokes suspicions among other citizens. Islamic schools or supplementary Qur'anic schools have even been accused of being a possible cause for Islamic radicalism and hindrance to the integration of Muslim students into society (Meijer 2009, p. 24). However, there are also problems in the inclusion of Muslims in public schools. While Muslim families view Islam as cultural capital, schools might view it as oppressive and a hindrance to students' academic achievement (Archer 2002). Parents' and community leaders' desire to protect their children have resulted in their willingness to establish private Islamic schools in, for example, Britain, Netherlands and some Nordic countries. The fear is that by being taught a non-Islamic curriculum by non-Muslim teachers in a class with non-Muslim pupils, Muslim children will eventually impact negatively on their Islamic identity. In terms of 
content, European textbooks commonly present the relationship of Muslims and Islam as conflictladen and difficult (Jonker \& Thobani 2009). In addition, the books may represent a "sanitised" ahistorical form of Islam that makes it easier to fit it into a western liberal conception of religions and omit features that seem incompatible with western values which is a serious form of misrepresentation that does not help in challenging Islamophobia and prejudices (Revell 2012, pp.64). The provision of separate Muslim schools aim to protect and nurture religious identity, and in other ways act as safe havens that resist assimilation of the Muslim community into the majority culture (Haw 1994; Modood et al. 1997).

However, many Islamic religious schools have adopted a similar kind of orientation to citizenship development as non-faith schools, where promotion of participation in a democratic society is actively encouraged. For instance, in some Dutch and British Islamic schools, there has been a mentality shift where the school environment is seen less and less as a place that protects 'children's religious identity against the un-Islamic influences of the mainstream society, but rather as a tool to prepare them for their role as active citizens' (Niehaus 2009). It is worth noting that the vast majority of Muslim parents in UK, for instance, choose to support the integration of their children to society by sending them to state schools (Mandaville 2007 230), and, for instance, are happy for their children to learn about other faiths as part of learning to respect others (Halstead 2009, p.195). The vast majority of the European Muslim students agreed that learning about different religions helps them not only to learn about others and "to live peacefully with them" but also in understanding their own religion and history (Jozsa 2009, p.155).

In terms of dealing with intrareligious differences, British, Swedish and Finnish IRE teachers tend to avoid differences of religious practices among denominations or teaching a particular school of thought, preferring to stress commonalities (Neihaus 2009, Berglund 2010, Rissanen 2012c). However, other studies have shown that some Muslim faith schools in the UK have made some tentative steps to build common ground between the Sunni and Shia traditions, in particular, by dispelling myths of the later (Panjwani 2014). While there is evidence of an openness among Muslim faith schools towards dealing with interreligious differences, struggles to engage in internal diversity in schools remains, where many schools are guilty of "seeking representation externally" while at the same time "suppressing it internally" (Panjwani 2012, p.122).

In any case, despite the heated debates concerning the teaching of Islam which seem to be in the front line in struggles concerning the integration of Muslims (see also Hefner 2007), there remains little research-based knowledge on how integration and social cohesion of European Muslims are actually promoted in the classrooms of different types of schools. This article attempts to draw links between public Finnish and Irish Muslim schools, forming the rationale behind this 
case study where classroom practices of promoting social cohesion in Islamic religious education are compared.

\section{IRE in Finland and Ireland}

The rationale for comparing Finland and Ireland lies in their notable similarities. They both are relatively small European countries that have become immigration-receiving countries since the early nineties (Scharbrodt et al. 2015; Sakaranaho \& Martikainen 2015). Their Muslim populations are rapidly growing and are notably heterogeneous. Finland differs mainly from other European Muslim immigration countries in that it has had a small Muslim population, Turkish Tatars, over a hundred years, yet post-war immigration started as late as at the end of 1980s. Nowadays, the Muslim population in Finland remains diverse, with Somalis, Arabs, Kurds, Kosovo Albanians, Bosnians and Turks as the largest groups (Martikainen 2010). In Ireland there are a reported 70,000 Muslims, making them the fastest growing minority in Ireland. Muslim immigration to Ireland has been diverse. Most groups come from African and Asian countries or European countries outside the EU, primarily from Turkey, Bosnia and Kosovo (Scharbrodt 2015, p.56).

Previous comparative studies concerning Islam and Muslims in Finland and Ireland have shown, for instance, that given the deeply embedded history of church-state relations in the two countries, both face similar challenges and issues as they relate to the governance of other religions including Islam (Sakaranaho \& Martikainen 2015). The response of these countries in their accommodation of Muslims and their educational needs has also been determined by the existing organisational structures. In Ireland, the State provides for free primary education, schools are established by patron bodies which define the ethos of each school and appoint boards of management to run schools on a daily basis. The vast majority of primary schools (96\%) in Ireland are owned by and are under the patronage of religious denominations- mainly the Catholic Church. A school of a specific religious community can provide religious education according to the traditions, practices and beliefs of that community. However, it may also provide a wider education about religion and must allow parents or guardians of other faith traditions to provide for religious education in their belief system[s] (Department of Education and Skills 2010). As of 2016, only two Muslim schools received funding from the Irish Department of Education and Skills and therefore are recognised as state-funded national public schools. Despite the exponential increase in the population, a Muslim secondary school has yet to be established.

The functions of a recognised school include the promotion of the moral, spiritual, social and personal development of students in consultation with their parents, having regard to the characteristic spirit of the school. The Irish primary curriculum imposes no specific requirements 
for RE, but the general aims serve as guidelines that generically emphasis the personal development of the child as well as the development of social cohesion; RE should 'enable the child to live a full life as a child and to realise his or her potential as a unique individual; enable the child to develop as a social being through living and cooperating with others and so contribute to the good of society and to prepare the child for further education and lifelong learning' (Government of Ireland, 1999). The State gives the Muslim patron the right to decide, devise and supervise Islamic religious education for the state funded schools.

The ethos of the schools is Islamic and IRE is taught in the Irish Muslim schools on a daily basis for approximately 30 minutes (see Sai 2017). The subject is divided into three sub-subjects: Qur'an, with a focus on reading and memorisation (see Sai 2017a); Arabic and Islamic studies, which focuses on the teaching of rituals, principles and general morals. Most of the time is allocated to the teaching of Qur' an and Arabic. Islamic studies, is taught from a textbook prepared by the patron. The textbook presents 'generic Islam' without any references to neither the DES's requirements nor the local Irish context where Muslims are living. There is no government support for IRE teachers who work on a part-time basis with a basic salary generated mainly from a small fee charged to the parents and local community donations. Most of the teachers do not possess any formal academic third level Islamic studies or pedagogical qualifications with some possessing an ijaza, a license to teach the Qur'an. There are very few religious schools in Finland, and no Islamic schools.

Religious education [RE] is taught, according to pupil's own faith, as a compulsory school subject, and students with non religious affiliation can choose to participate in the learning of ethics. RE should not include the practice of religion in the classroom, and dialogue between different religions and worldviews is encouraged. Students from minority religions have a right to their own $\mathrm{RE}$, if at least three students reside in the same area and their parents request it. In 2010, despite the increasing plurality of Finnish society, 93\% of comprehensive school pupils still participated in Evangelical Lutheran teaching, only $3 \%$ in ethics, $1 \%$ in Orthodox teaching and $2 \%$ in teaching according to other religions (Statistics Finland 2011). However, the situation is different in urban areas of southern Finland, where the relative number of students participating in the study of ethics and minority religions is considerably more. The National Board of Education plans the curricula for religions and the National core curricula stress both the acquisition of knowledge about religion and the personal development of pupils.

The framework for Finnish IRE is very different from its Irish counterpart. There is a national framework curriculum for religions including Islam, which has not been made in close cooperation with the Muslim communities, although some Muslim teachers were consulted (Sakaranaho 2006, 359). The Finnish curriculum emphasises the development of Islamic identity 
and the contents mainly focus on the Islamic tradition, but teaching should also cover other religions (Finnish National Board of Education 2006a, 2006b). Furthermore, students are to be aided in understanding the significance of Islam for the wider society, and aims of tolerance and respect for difference are emphasised. However, the willingness to encounter difference is pursued in the IRE curriculum by the promotion of values such as mutual understanding, tolerance and respectful attitudes where teaching should also cover the plurality inside the Islamic tradition.

Despite the plurality of the Muslim population in Ireland and Finland, due to practical limitations, in both countries "general Islam" is taught (Sakaranaho 2006, 364). In Finland, this approach has brought challenges and created suspicions among the parents, nonetheless teachers of Islamic education still give preference to the current model. In principle, RE teachers in Finland do not have to be members of the tradition they teach. At the moment, unlike in Ireland, IRE in some schools is taught by non-Muslim teachers, which has caused tensions and resulted in some parents requesting their children to not participate in the IRE lessons. The concerns from parents often arise due to the fact that most of the Muslim teachers of Islamic education do not possess formal qualifications to teach the subject. The implications of which are discussed towards the end of this article.

\section{Data and methods}

This article draws from two case studies conducted in Finland in 2010-2014 and Ireland in 20142016. Both case studies used ethnographic methodologies and concentrated on three IRE teachers in each country, six in total. Data in both contexts were recorded via classroom observations and recorded by means of extensive field notes. In the two Irish primary schools, referred to here as school A and school B, 22 parents and six teachers were interviewed. In two Finnish comprehensive schools and one upper secondary school, semi-structured interviews were conducted with three teachers and 16 students (aged between 13-19). The Finnish teachers were familiar and committed to the RE curriculum and Finnish educational values, but only one of them had a formal qualification. All the Irish and Finnish teachers were experienced teachers and considered themselves to be practicing Muslims.

All interviews in both studies were recorded and transcribed. Data was analysed by means of inductive qualitative content analysis. The Finnish data has previously been analysed from the perspective of students' identity and value negotiations and how teachers supported these in the classroom (Rissanen 2012a, 2012b, 2012c, 2014). In this article, our comparative study discusses how social cohesion is promoted in Finnish and Irish IRE classrooms, with a focus on three main aspects. These include intra-religious cohesion, inter-religious cohesion and commitment to society. 


\section{Results}

\section{Promoting intra-religious cohesion}

In a broad sense, teaching IRE in both countries in what might be referred to as general Islam seemed to be the result of a desire on the part of the IRE teachers to increase unity and commonality among Muslims. However, this may have been at the risk of ignoring the fact that Muslim pupils, who belonged to different Islamic sub-groups, had a diversity of cultural backgrounds. This approach is likely to cause tensions outside school if the general values taught were not necessarily affirmed by pupils' parents. In both countries, there were students from both Shia and Sunni denominations. Considering that both denominations share many fundamental tenets, there appears to a valid justification for teaching general Islam. While the Finnish curriculum for IRE requires the teaching of "general Islam", the Irish teachers were not subject to such restrictions. However, in both countries, when the finer details of Islam emerged in the classroom, the dominance of a Sunni interpretation of Islam was evident in the observed lessons. This is how a Finnish Shia-student experienced the teaching:

Every now and then...like the last time, with this teacher, we were in another school, he told us about a prayer or one part of that prayer. It's a bit different for us, and when I told him that, he started, like, yelling at me. And I was like... and he was like, 'No, it is not different', and I was like, 'Yes it is, believe it or not'. Every now and then this happens (Interview with Finnish 16-year old girl).

This student was very frank and did not fear confronting the teacher during the lessons. She candidly spoke of having quarrels with the teacher and that her parents did not see much value in the IRE taught. She thought the lessons concentrated too much on the 'basics'; a criticism shared by many of the students, both Shias and Sunnis. She had a perception that this was because the Finnish law prohibited teachers from discussing differences between different denominations in Islam:

Researcher: Have you asked about the differences?

Student: I have, but they won't...they're like, this is general teaching. I mean, of course they say that yes, there are differences, but we learn general Islam. You know, because according to Finnish law, they should bring the differences forward, so that there would not be any troubles or something like that, I don't know.

Teaching children common values shared by both Sunni and Shia students provided a means of stressing group identification and distinctiveness in an attempt to strengthen religious unity among the pupils, despite the obvious variations that existed in their beliefs, backgrounds and cultures. There were remarkable similarities in Finnish and Irish teachers' ways of handling the heterogeneity in their classrooms. Despite the regular questions on and derogatory remarks about 
Shia Muslims by some Sunni pupils, they felt that it was not appropriate to teach about the various schisms. In both countries the students' eagerness demonstrated a natural inquisitiveness towards understanding the differences between Muslims and their practices, yet teachers often glossed over them without getting into any detailed discussion. An example, from Irish school A, is outlined below.

Teacher Ali says to the pupils 'The companions used to pray in the mosque... and this is a sign of faith... some people used to go to the mosque just to be seen but they weren't really Muslims'. A student responds 'Like Shia'. Another says in Arabic 'Munafiqeen' [hypocrites]. Ali affirms munafiqeen and ignores the comment previous to it. A student says 'My dad always prays in the masjid [mosque] he never prays at home' (Field notes from Irish school A).

The teacher chose not to challenge the derogatory comment made by the pupil that put Shia Muslims in a negative light and explained in the interview that:

The children are too young to go into these matters and it's not a topic we can talk about in five minutes or 10 minutes. It needs to be done thoroughly number one and it depends on the child who is asking the question. Maybe if the child is asking the question is rough and straightforward so if he [sic] comes in contact with someone who has these thoughts he will be very strict with him[sic]. So it depends child by child. So the Sunni-Shia thing the kids don't need to know about it.

This view seemed to echo the views of Finnish IRE teachers who seemed more comfortable discussing the diversity of Muslims with the older students only. However, there were instances in which it seemed that the teachers attempted to model openness and positive attitudes. These included, for example, mentioning their 'good friends at the Shia mosque' or the fact that they had visited a Shia mosque previously.

Due to the extreme sensitivities related to the issues between Shias and Sunnis, teachers endeavored to promote cohesion by concentrating on commonalities. However, this attempt to promote peaceful coexistence of Finnish/Irish Muslims, by providing a monolithic view of Islam that ignored the differences within, implies that teachers' use power as agents of governance and identity politics. This approach, perhaps to some extent in the short term, may appear effective in harmonising relationships between the two denominations, however, as the populations of Muslims continue to grow and political tensions intensify, glossing over 'difference', particularly for older children appears to be ineffective. Cases of bullying among pupils, name-calling, parents' opting to take their children out of the schools and, in some cases, even refusing them to take part in IRE lessons highlights undeniably the kind of sensitive issues that need to be addressed if intra-religious cohesion is to be nurtured. $t$ exist when . 


\section{Promoting interreligious cohesion}

Instruction in one specific religion, emphasising only the pupils' own religious beliefs is often viewed negatively by those who object to faith-based schools or confessional religious education. Maybe the most significant difference between Finnish and Irish forms of IRE is that, in the former, teaching about other religions is included in the IRE curriculum. However, respect for people of other faiths was often referred to in both classroom contexts. Promotion of inter-religious cohesion is not only about teaching about other religions, but teaching about how to encounter them, as Muslims. Questions like 'Can I wish my friend a merry christmas even though it is their holiday'?; 'If you are at work or at school, you can't pray there, right?; 'Why Islam and Christianity are separate religions even though they have so much in common'?; 'What happens to people who change their religion'? and 'What does the Qur'an say about people who believe in God, but not in any religion'? were commonly asked by Finnish students during the class observations. All the teachers ironically promoted an open way of dealing with other religions - much more open than in the case of intra-religious differences (see also Rissanen 2012c). In the views of some Irish parents and teachers, learning about Shia perspectives on Islam was considered more of a threat to their children's religious identity than learning about other religions.

Some Irish Muslim parents were open to the idea of teaching about other beliefs, and that it could enable their children to interact positively with others and understand their beliefs in later life. One parent explained why this was important for his son.

Because to learn about other religions you can understand if they do something wrong. If someone asks 'Why you are a Muslim'?, you can explain because you know his [sic] religion already. Like in our country, we are not allowed to learn about other religions. I find it is a bad idea because how can you discuss views with other people and you don't know his [sic] religion. It will be difficult (Parent 1, Irish school A).

However, those parents who agreed with their children learning about other religions, they did stipulate that it ought to be conducted in a way comparative approach with Islam. This view was expressed by a parent from school A.

Teach them the basics of Islam, like in Educate Together [schools], they teach that [Muslims] fast Ramadan, Jesus is a Prophet, and those kinds of things. The Christian believes this, eats this but you don't have to condemn them. You have to say it in a good way (Parent 5, Irish school A).

Most of the Irish Muslim parents disagreed with the idea of learning about other beliefs at primary level as it might cause confusion among children and negatively affect their identities as Muslims. However, most parents had no objection with their children being taught comparative RE at secondary-level. All the IRE teachers unequivocally asserted that given the limited time allocated to IRE that a focus solely on learning Islam was a priority.

Although no parents were interviewed in the Finnish study, the teachers shared this view that 
the legitimacy of introducing students' to other faiths depended on whether the students had a sufficient understanding of their own tradition. This view was expressed by one student who described the reaction of one of his parents:

Student: In the sixth grade...we were studying about all these...Buddhists and...well, my father takes a look at the religious education study book and is like...oh, I thought this was an Islamic education study book (laughs and demonstrates her dad being a bit surprised), but suddenly there were things about Judaism and Buddhism.

Researcher: Ok, so what did your dad think about that?

Student: He was like...are you studying Buddhism? No, this is the course about world religions... ok, I got a little startled.

Researcher: So did he think this was a bad thing?

Student: No, he was like...it is a good thing to learn these things but...he said that it is better to study Islam first, then move on to other religions (Interview with Finnish 14-year old girl).

These reactions highlight the Muslim parents' worries related to challenges of religious upbringing and transfer of family tradition in western contexts, complicated further by their minority position. The idea, first of all, of gaining sufficient understanding of one's own tradition to assist pupils in developing understanding of others, skills for dialogue and social cohesion - all of which have been considered hallmarks of RE (see Schweitzer 2007). However, this ideal has, for the most part, been ignored from current discussions and debate. Finnish RE has also been influenced by these trends. While RE still is organised in denominationally separated groups, the new 2014 core curriculum introduced the teaching about other religions for lower levels.

Recently, Ireland's National Council for Curriculum and Assessment (NCCA) has recently proposed to the DES the introduction of a curriculum in world religions and ethics for primary to be taught at primary level, including Muslim schools, as a separate subject. However, the Catholic Church has resisted such efforts by the State to introduce this on the basis on that this would breach the rights of demoninational schools to uphold their own religious ethos (Donnelly 2016).

\section{Promoting commitment to society}

The Finnish IRE teachers' position as agents of identity politics was also seen in their active promotion of 'Finnish Muslim identity' in the classroom. They endeavored to promote citizenship "through" religion by pairing the conceptions of 'good' Muslim and 'good citizen' while emphasising the compatibility between Finnish and Islamic norms and values (Rissanen 2012b). The teachers educated about liberal educational values such as autonomy and tolerance by representing these as Islamic virtues. Furthermore, they seemed to actively promote the students' loyalty to their country by emphasising the right to IRE as an act of recognition by the state, in addition to informing them that their Muslim identities were legitimate and supported by the state (Rissanen 2014). For the students, the value of IRE often lied in how it supported their capability to 
live as Muslims in Finland:

Researcher: What does IRE mean to you and why is it important?

Student: It's very important. You learn about these things in Finnish, so if a Finn asks you an important question, you are able to explain to her in Finnish... a person who does not know anything about Islam, you can explain and he/she understands what you are talking about (Interview with 18-year old girl).

In contrast, given the heterogeneity of Muslim students in the Irish classrooms, some of whom were not born in Ireland, the teachers did not emphasise the importance of an Irish Muslim identity. However, one of the expectations of the DES concerning RE is that it should instill values that promoted a willingness to contribute to the general good of society, and this was done in a similar manner to Finnish IRE. Furthermore, the concepts of contributing to the good of society and tolerance were not interpreted as liberal values but as Islamic ones in and of themselves.

The narratives in both the Irish and Finnish contexts stressed the general importance of contributing positively to society through the embodiment of Islamic values and beliefs. In the former, most of the parents and teachers interviewed supported the idea of integration with nonMuslims on condition that doing so did not contravene their own Islamic values. Some parents even called for more specific content and teaching on the best ways young Muslims could integrate effectively in their community. One parent said:

There are no cases [in the textbook] of how to deal with non-Muslims and this is a weakness in the curriculum. It lacks real cases or stories, anything that can help the kids in how to deal with non-Muslims and how they shouldn't be judgmental. Because when non-Muslims see Muslims being very judgmental they don't like this religion because they think it is all about the appearance or what people see, for example like hijab. It is about the inside before the outside (Parent 6, Irish School A).

During the observations in both contexts, it was noted that the children were often encouraged to be decent citizens and to lead others by example through their Islamic values and beliefs. Teachers' regarded a secure Muslim identity as a prerequisite and necessary step in equipping students with the ability to participate in the common culture of the country in a balanced manner.

\section{Conclusion}

In this comparative case study between IRE as a subject in Finland and Ireland, notable differences emerged in the content and its administration, particularly the extent of state involvement. This further dismisses the notion of defining IRE in homogenous terms. However, despite these differences, issues related to intra-religious and interreligious cohesion as well as commitment to society were negotiated in relatively similar ways. Yet, these aims were explicitly stated in the 
Finnish IRE curriculum only, hence why they were more explicitly pursued in the classroom. Some Irish Muslim parents did request more contextual IRE that incorporated citizenship education and addressed societal issues that affected their children. Amidst the disparate voices within Islam there exists an 'internal [emphasis in original] struggle for space' (Berglund, 2010, p. 208) between the various interpretations and expressions and this was, perhaps, nowhere more clearly demonstrated than in the views of the participants in this comparative study. The various ways in which teachers are found to deliver and negotiate the content of IRE indicates that it remains a space of internal governance whereby the role of the teacher becomes even more salient (see Sakaranaho, forthcoming).

According to the 'traditional' view in the scholarly field of religious education (individual and collective) identity development is a necessary prerequisite for peaceful coexistence, a conviction shared also by the teachers and parents in this study. It can be stated that the potential "power" of both Irish and Finnish IRE in promoting social cohesion, in some respect, relies on the fact that they can offer a space for this kind of identity negotiation process, interpreted here as a form of internal governance of religion. However, in Finland, as this case study shows, the development of IRE as this kind of space remains compromised. The current legislation makes it possible for non-Muslims to teach IRE, and in many large Finnish cities there are currently non-Muslim IRE teachers. In these situations, the IRE classroom has become more a setting for external rather than internal governance, in terms of the context of the curriculum and its delivery. In theory, there is a clear logic that religious affiliation of a teacher who teaches a knowledge based subject in public schooling is not required. However, drawing from an Islamic traditional viewpoint on education where teachers have played an important role as 'models for imitation' (Renaerts, 1999, p. 291) and are perceived as a "committed embodiment of the message being taught" (Hewer, 2001, p. 521), the effectiveness and credibility of a non-Muslim teaching IRE as an subject that has the ability to promote social cohesion through religion remains questionable.

In Ireland, the agency of a Muslim patron in administering, supervising and determining IRE perhaps gives less scope for conflict than in some other countries. However, at the same time, the hands-off approach of the Irish DES matched with its outdated RE guidelines that predate the 9/11 era, implies that IRE does not easily provide an opportunity to become a space, whereby religious education at grass-root level can practically assist Muslims to live in a multicultural society and contribute to the development towards societal cohesion. Given the various challenges young Muslims face living as minorities in secular communities and some as minorities within a minority, new life is needed into the content and pedagogy of IRE insofar as it is relevant and practical to their lives and reflects the diversity of their communities. Without any regular independent accountability over how IRE is designed and implemented, the extent of how the subject effectively 
serves those needs living in the twenty first century remains uncertain.

The new role of RE as a setting for the governance of religious minorities, creates a need to pay attention to the role of IRE teachers as agents of governance, whose religious identification is definitely not irrelevant when the legitimacy of religious education is evaluated from a minority perspective. Furthermore, the power of religious education to promote social cohesion relies partly in its ways of supporting the students' value and identity negotiations and their efforts to balance between their loyalties to their religious tradition and to society as a whole. This article indicates that while what is taught to young Muslims has often been at the forefront of the debate, recognising the influential role of IRE teachers in the delivery of Islam, and their potential impact in the promotion of social cohesion at various levels to younger generations of Muslims, is equally if not more important. Further research on the views and approaches of IRE teachers teaching Islam in western contexts is a desirable step in the right direction. Professional development and training programs where ideas and experiences can be exchanged including on ways to improve pedagogy and enrich the classroom by providing tools to engage with theological and moral 'differences' would be of immense benefit to IRE teachers and school leaders. While being a relatively sensitive and challenging issue for some, an exploration into ways of engaging with intrareligious diversity among Muslims cannot be ignored.

If the importance of promoting social cohesion is to be taken serious, Islamic education needs to become a research-based interdisciplinary academic field within Irish and Finnish university structures, as it is in other European countries such as Germany and Austria whereby state academic posts concerned specifically with Islamic studies and pedagogy as well as theology operate within existing university structures. Recognising the diversity that exists in the classroom is only the first stage. The next step requires some form of pedagogical, philosophical and theological orientation in order to improve educational experiences of young Muslims as they navigate their identities within evolving pluralist societies.

\section{References}

Archer, L. (2002). Change, Culture and Tradition: British Muslim Pupils Talk about Muslim Girls' Post-16 'choices'. Race Ethnicity and Education, 5(4), 359-376.

Aslan, E. (Ed.) (2009). Islamic education in Europe. Wien: Böhlau.

Berglund, J. (2010). Teaching Islam. Islamic religious education in Sweden. Münster: Waxmann.

Central Statistics Office. (2012). Profile 7 Religion Ethnicity and Irish Travellers. Retrieved 13 April from

http://www.cso.ie/en/census/census2011reports/census2011profile7religionethnicityandirisht ravellers-ethnicandculturalbackgroundinireland/

Donnelly, K. (2016, 28 Nov). Church's Backlash Blocks Change in Religion Classes. Irish 
Independent. Retrieved $5^{\text {th }}$ May 2017 from http://www.independent.ie/irishnews/education/churchs-backlash-blocks-change-in-religion-classes-35249798.html

Driessen, G., \& Merry, M. S. (2006). Islamic Schools in the Netherlands: Expansion or Marginalization. Interchange, 37(3), 201-223.

Finnish National Board of Education. (2006a). Framework for comprehensive curriculum for other religions. Helsinki: Author.

Finnish National Board of Education. (2006b). Framework for upper secondary curricu-lum for other religions. Helsinki: Author.

Jackson, R. (2014) 'Signposts': Policy and Practice for Teaching about Religions and NonReligious Worldviews in Intercultural Education, Strasbourg: Council of Europe Publishing.

Jonker, G. \& Thobani, S. (2009) Narrating Islam: interpretations of the Muslim world in European texts. London: Tauris Academic Studies.

Koenig, M. (2007). Europeanising the Governance of religious diversity: an institutionalist account of Muslim struggles for public recognition. Journal of ethnic and migration studies 33(6), 911-932.

Halstead, M. (2009). Islamic Education in the UK. In E. Aslan (Ed.), Islamic Education in Europe (pp. 179-202). Vienna: Boehlau.

Haw, K. (1994). Muslim girls' schools: A conflict of interests? Gender and Education, 1(6), 63-76.

Hefner, W. R., Zaman, Qasim Muhammad. (2007). Schooling Islam: The Culture and Politics of Modern Muslim Education (W. R. Hefner, R Zaman, Qasim Muhammad Eds.): Princeton: Princeton University Press.

Heimbrock, H.-G. (2007). Self-taught professionality. Muslim teachers engaged in teaching Islamic issues between curriculum and lifeworld in German public schools. In C. Bakker, \& H. Heimbrock (Eds.), Researching RE teachers, RE teachers as researchers. Münster: Waxmann, 175-192.

Government of Ireland. (1999). Primary School Curriculum Dublin: The Stationery Office.

Himanen, T. (2012). Cultural Diversity, Social Cohesion, Religion: Core Values and Educational Policies in Four European. Nations. Turku: University of Turku.

Jozsa, D.P. (2009). Muslim Students Views on Religion and Education. In A. A. Veinguer, D. Gunther, D. Jozsa \& T. Knauth (Eds.), Islam in Education in European Countries. (pp. 131158). Münster: Waxxman.

Lightfoot, L. (2005, 18 Jan). Muslim Schools Accused of 'Undermining our Society'. The Telegraph. Retrieved $20^{\text {th }}$ July 2013 from

http://www.telegraph.co.uk/news/uknews/1481425/Muslim-schools-accused-ofundermining-our-society.html

Mandaville, P. (2007). Islamic Education in Britiain: Approaches to Religious Knowledge in a Pluralistic Society Schooling Islam: The Culture and Politics of Modern Muslim Education (pp. 224-242). Princeton: Princeton University Press.

Maréchal, Brigitte (2002). Teaching Islam at Publicly financed schools in Europe. In W.A.R.Shadid, \& P.S. Koningsveld, (Eds.), Intercultural relations and religious authorities: Muslims in the European Union. Leuven: Peeters, 138-148.

Martikainen, T. (2010). Finland. In J. Nielsen (Ed.), Yearbook of Muslims in Europe. Leiden: Brill

Meijer, W.A.J. (2009). Tradition and future of Islamic education. Münster: Waxmann.

Modood, T., Berthoud, R., Lakey, J., Nazroo, J., Smith, P., Virdee, S., \& Beishon, S. (1997). Ethnic Minorities in Britain: Diversity and Disadvantage. London: Policy Studies Institute.

Niehaus, I. (2009). Emancipation or disengagement? Islamic schools in Britain and the Netherlands. In A.A. Veinguer, G. Dietz, D-P. Jozsa\&T. Knauth (Eds.), Islam in Education in European Countries. Pedagogical Concepts and Empirical Findings. Münster: Waxmann, 113130.

Panjwani, F. (2014). Faith-schools and the religious other : the case of Muslim schools. In J. Chapman, M. Reiss, S. McNamara, Y. Waghid (Eds.), International Handbook of Learning, Teaching and Leading in Faith-Based Schools. London: Springer. 
Panjwani, F. (2012). Why did you not tell me about this?: Religion as a challenge to faith schools. In H. Alexander, A. Agbaria (Eds.), Commitment, character, and citizenship : religious education in liberal democracy. New York: Routledge.

Revell, L. (2012). Islam and education. The manipulation and misrepresentation of a religion. Stoke on Trent: Trentham Books.

Rissanen, I. (2014). Developing religious identities of Muslim students in the classroom: a case study from Finland, British journal of religious education 36(2): 123-138.

Rissanen, I. (2012a). Teaching Islamic education in Finnish schools: A field of negotiations, Teaching and Teacher Education 28 (5): 740-749

Rissanen, I. (2012b). How Finnish Muslim students perceive and deal with religious and cultural difference: negotiating religious tradition with modern liberal and postmodern ideals, Education Research International (2012), DOI:10.1155/2012/978317.

Rissanen, I. (2012c). Developing students' willingness to encounter difference-teachers practices in Islamic education. In T. Van Der Zee and T. Lovat (Eds.), New Perspectives on Religious and Spiritual Education. Münster: Waxmann, 39-55.

Sai,Y (2017). An Exploration of Ethos in Irish Muslim Schools: Ethnographic Insights and Perspectives from Parents and Teachers. Journal for Beliefs and Values. Published online, DOI:10.1080/13617672.2017.1290374.

Sai,Y (2017a). Teaching Qur'an in Irish Primary Muslim Schools- Curriculum, Approaches, Perspectives and Implications. British Journal for Religious Education. Published online, DOI:1080/01416200.2016.1269723.

Schweitzer, F. (2007). Religious individualization: New challenges to education for tolerance, British Journal of Religious Education, 29(1), 89-100.

Sakaranaho, Tuula (forthcoming), The Governance of Islamic religious education in Finland: Promoting "General Islam" and the Unity of all Muslims, Islam in the Margins of Europe, Eds. Tuomas Martikainen, Adil Hussain Khan, Jose Mapril, Leiden: Brill.

Sakaranaho, T. \& Martikainen, T. (2015). The Governance of Islam in Finland and Ireland. Journal of Religion in Europe 8 (2015), 7-30.

Sakaranaho, T. (2006). Religious freedom, multiculturalism, Islam: Cross-reading Finland and Ireland. Leiden: Brill.

Schardbrodt, O. (2015). Muslim Immigration to Ireland after World War II. In Scharbrodt, O., Sakaranaho, T., Khan, A. H., Shanneik, Y., \& Ibrahim, V. (2015). Muslims in Ireland. Edinburgh: Edinburgh University Press, 49- 74.

Statistics Finland. (2011). Education: Subject Choices of Students 2010. Helsinki: Statistics Finland. Veinguer, A.A., Dietz, G., Jozsa, D-P. \& Knauth, T. (2009). Introduction. In A.A. Veinguer, G. Dietz, D-P. Jozsa\&T. Knauth (Eds.), Islam in Education in European Countries. Pedagogical Concepts and Empirical Findings. Münster: Waxmann, 11-14.

Wintour, P. (2014, 18 May). Code of Conduct Drawn up for UK Madrasas. The Guardian. Retrieved 12 August 2015 from http://www.theguardian.com/politics/2014/may/18/code-of-conduct-uk-madrasas. 